2019

Does leadership exist in early childhood education in Tanzania?

Fortidas Bakuza

Follow this and additional works at: https://ecommons.aku.edu/eastafrica_ied

Part of the Early Childhood Education Commons 


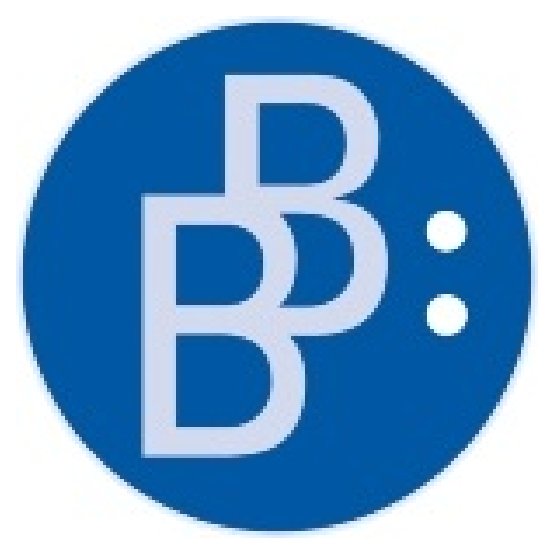

Chapter Title: Does leadership exist in early childhood education in Tanzania?

Chapter Author(s): Fortidas Bakuza

\section{Book Title: Leadership in Early Education in Times of Change}

Book Subtitle: Research from five Continents

Book Editor(s): Petra Strehmel, Johanna Heikka, Eeva Hujala, Jillian Rodd and Manjula Waniganayake

Published by: Verlag Barbara Budrich

Stable URL: http://www.jstor.com/stable/j.ctvmd84fc.12

JSTOR is a not-for-profit service that helps scholars, researchers, and students discover, use, and build upon a wide range of content in a trusted digital archive. We use information technology and tools to increase productivity and facilitate new forms of scholarship. For more information about JSTOR, please contact support@jstor.org.

Your use of the JSTOR archive indicates your acceptance of the Terms \& Conditions of Use, available at https://about.jstor.org/terms

This content is licensed under a Creative Commons Attribution-ShareAlike 4.0 International License (CC BY-SA 4.0). To view a copy of this license, visit https://creativecommons.org/licenses/by-sa/4.0/. 


\title{
Does leadership exist in early childhood education in Tanzania?
}

\author{
Fortidas Bakuza, Agha Khan University, Tanzania
}

\begin{abstract}
Early Childhood Education (ECE) is the part of basic education that lays the foundation to the other levels of education. It is an area that requires leadership specialization based on the importance of this level and the age of children served and the current literature suggest that the nature and context of ECE makes it unique and worthy of independent examination and support mechanisms for quality improvement. This paper presents findings from a larger study conducted in Tanzania, East Africa to assess the differences between stated and implemented policies in Early Childhood Education leadership and it identifies issues such as ECE professional background, supporting structure, budget and resource allocations and gender and leadership that should be addressed in realization of a balanced Leadership in Early Childhood in Tanzania and other similar countries.
\end{abstract}

\section{German Abstract}

Frühe Bildung ist Teil der Grundbildung und legt das Fundament für andere Stufen der Bildung und Erziehung. Sie ist ein Bereich, der eine Spezialisierung der Leitung erfordert, die der Bedeutung dieser Stufe und dem Alter der Kinder gerecht wird. Die aktuelle Literatur empfiehlt für die frühe Bildung Unterstützungsmechanismen zur Qualitätsverbesserung und unabhängige Prüfungen, da die frühe Bildung aufgrund ihrer Natur und ihres Kontexts einzigartig ist und es wert sein sollte. Dieses Papier stellt die Ergebnisse einer größeren Studie vor, die in Tansania, Ostafrika, durchgeführt wurde, um Unterschiede zwischen vorgegebenen (stated) und implementierten Politiken in der Leitung von Kindertageseinrichtungen empirisch zu belegen. Die Studie identifiziert Themen wie den professionellen Hintergrund, Unterstützungsstrukturen, Budget und Ressourcenallokation sowie Gender und Leitung, die bei der Realisierung einer ausgewogenen Leitungskultur in der frühen Bildung in Tansania und ähnlichen Ländern aufgegriffen werden sollten.

\section{Finnish Abstract}

Varhaiskasvatus on osa perusopetusta ja luo perustan muille koulutustasoille. Varhaiskasvatus vaatii johtamisen erikoistumista tämän tason merkityksellisyyteen ja lasten ikätasoon. Uusin kirjallisuus osoittaa, että varhaiskasvatuksen luonne ja konteksti tekevät siitä ainutlaatuisen ja tutkimuksen sekä tukevien mekanismien arvoisen sen laadun parantamiseksi. Tässä luvussa esitetään tuloksia Itä-Afrikan Tansaniassa suoritetusta laajemmasta tutkimuksesta. Tuloksien avulla voidaan arvioida eroja var-

https://doi.org/10.3224/8474219910 
haiskasvatuksen hallinnollisten ohjeistusten ja toteutettujen toimintatapojen välillä. Luvussa nostetaan esille aiheita varhaiskasvatuksen ammatillisesta taustasta, tukea antavista rakenteista, budjetin ja resurssien kohdentamisesta sekä sukupuolesta ja johtajuudesta, jotka tulisi huomioida tasapainoisen varhaiskasvatuksen johtamisen toteuttamiseksi Tansaniassa ja muissa samankaltaisissa maissa.

\section{Background - Education governance in Tanzania}

Tanzania is a developing country in Africa, which in its efforts to improve the quality of life of its citizens a lot is being done, and yet a lot of issues are still at different levels of development. The governance of the education in Tanzania is divided between the central ministry and the local government. The Ministry of Education, Science and Technology is responsible for policy, curriculum and program development. It is also responsible to oversee quality control and assurance measures. The ministry is also responsible for the education budget development but the actual implementation of day-to-day education activities are decentralized.

The Local Government Authorities (which during this study were under the Prime Minister's Office but now under the President's Office) are responsible for the overall implementation, management and supervision of education at local government authorities. However, the Ministry of Education and its institutions develop policies, curriculum and syllabi, which are operationalized by the local government authorities.

Primary schools are managed and supervised by the local government. Primary education (Basic Education) includes a compulsory one-year of pre-primary (Early Childhood Education) and seven year of primary education.

In Tanzania public education system, education leadership positions at all levels are filled by promotion not training. All teachers are expected to take courses on leadership and ECE (it is mandatory during their pre-service training) together with other courses (Mtahabawa, 2010). However, these courses tend to be introductory and in most cases not well taught.

\section{Leadership in Early Childhood}

Leadership is reframed as a shared responsibility amongst all professionals, tertiary educational institutions, professional organizations and those who work and interact with young children and their families (Stamopoulos, 2012). It is a shared responsibility for all early childhood professionals who must tackle educational change (Ho, 2011). The quality of early years' service provisions is directly linked to the quality of leadership and management of early years' settings (Ang, 2011; Muijs, Aubrey, Harris, \& Briggs, 2004). 
Leadership in Early childhood may be well perceived in the ways early childhood professionals share a reciprocal process to pursue chances that lead to a desired future Stamopoulos (2012). According to Stamopoulos (2012), leadership is being constructed as each person interacts and influences another while contributing to a shared vision. She emphasizes that leadership is not based on position but all early childhood professionals who make decisions about educational practice in their work are perceived as leaders in their own right (Stamopoulos, 2012, p. 42).

Early Childhood Education is gaining attention at national and international levels but there is limited attention on Early Childhood leadership. Issues of capacity and perceptions of those who work in the field of ECE have not been brought to the spotlight. Literatures suggest that it seems "almost inconceivable that the leadership practices of those working within EC are not being taken seriously" (Muijs et al., 2004, p. 167). In Tanzania, quality ECE programs will allow children to enter primary schools better prepared to learn and succeed. However, at the time of this study there was no research that had linked teachers, head teachers/principals and policy makers' professional and pedagogical knowledge that influence leadership practice in ECE in Tanzania.

\section{Research questions}

The study was guided by questions that investigated the actual implementation of national developed policies at national, district and school levels. Three questions are presented below:

1. What professional background do teachers, head teachers and policy makers have that support their implementation of policy and programs related to ECE in Tanzania?

2. What supporting structures are in place to empower teachers, head teachers and policy makers to assume effective leadership in ECE in Tanzania?

3. What factors are viewed as barriers affecting leadership roles about ECE in Tanzania?

\section{Literature Review}

There is a growing body of literature on scientific evidence about child development and the contribution of early care and interventions in the future development of young children and their families. Study findings indicate that there is now a remarkable convergence of new knowledge about the developing brain, the human genome, molecular biology, and the interdependence of cognitive, social, and emotional development that offers scientists and policymakers an ex- 
ceptional opportunity "to launch a new, science driven era in early childhood policy and practice" (Center on the Developing Child, 2007, p. 7; National Research Council and Institute of Medicine, 2000; Ramgopal, Dieterle, Aviles, McCreedy, \& Davis, 2009).

The knowledge on economic returns may help parents, teachers and policy makers in making right and timely choices. Investing in early childhood has multiple benefits for children themselves, their families and the nation as whole (Heckman, 2006). For governments in developing countries like Tanzania, timely investment in Early Childhood Development programs may be a way to break the vicious circle of poverty.

\section{Methodology}

This study used Critical Qualitative Research approach with a qualitative case study research method for data collection, analysis and reporting of the findings. Merriam (2009) argues that critical education research "queries the context where learning takes place, including the larger system of society, the culture and institutions that shape educational practice, the structural and historical conditions framing practice" (p. 10).

The interview was the main source of data collection in this study, with government document analysis being supplemental (Bogdan \& Biklen, 2007). Different government documents that show data on enrollment, staff training and budgeting were reviewed. Efforts were made to review available documents for the last five years (2008-2013) and some reports covered a longer period than five years as they were available in order to assess the trends in enrollment of children, teacher training and budget allocations.

The participants in the study were identified from a cross-sectional of policy makers at national level all the way to classroom teacher and provided the understanding of the process of implementing the policy at national level, district levels and the impacts of their decisions on teaching and learning at school level.

\section{Findings}

The data from the documents review indicate increase and decrease in enrollment across years and projecting of teacher recruitment to meet the increasing demand. However, it is clear that there is still limited funding for primary education. It is clear that ECE is under-resourced with no explicit budget allocation in the overall budget allocation and therefore it has not been receiving direct funding from the government budget. The data have also indicated the shortage of teachers to meet the increased demands. 


\section{ECE professional background}

In Tanzania, Early Childhood Development professionals are very few and those few are mainly found at classroom level. The decision-making chain starts at the national level and it ends at the classroom level. Therefore it is important to have people in the decision-making loop who are knowledgeable about the importance of Early Childhood Education at all levels. The professional background of national level participants in this study varied from a graduate course on Early Childhood to only those who attended a few seminars here and there on Early Childhood:

If I have to talk about the experience, I think I have understood ECE to a greater extent because I have participated in so many things including research, surveys and documents productions that have helped me to understand the importance of ECE (National Level Officer).

The situation was not different for the other participants at district and school levels:

When I came here in the District Education Officer also assigned me to oversee the Early Childhood Development unit and the child rights desk. So I started getting some training on Child Rights, Early Childhood Development (ECD) and through those seminars, I am where I am today (District Education Official).

I don't recall it [leadership training in ECE] and it might have been very little to be remembered. Basically, there have been some seminar and workshops on managing ECE classes as part of our in-service capacity building (Primary School Head Teacher).

The quotes above indicate that there had not been any training on leadership focused on Early Childhood Education. Participants at national, district and school levels had attended seminars and workshops in ECE that are helpful in professional development, but they cannot replace teacher training. The professional status has not improved and it is posing a threat to the quality of ECE in Tanzania.

\section{Supporting structure}

Findings indicate that there are no supporting structures for professional growth and policy implementation to Early Childhood Education. However, participants indicated their level of commitment to ECE despite the limited support they could not clearly identify the supporting structures in fulfilling their leadership roles apart from individual initiatives; 
I have not received any leadership training [laugh]. I have received training I think once (District Official).

In my leadership position as head teacher to have training specifically on how to lead the school, that's one I haven't attended any training. There is no any formal leadership training (Primary School Head Teacher)

It was clear from interviewing teachers that because they did not see any open opportunity to them for leadership training, they could not plan or even think about attending leadership trainings. It appears that teachers are required to cover the tuition fees personally if they want to attend leadership training. They were concerned about the lack of formal structures to improve their leadership practice given that the education landscapes were changing:

I think training is important because things are constantly changing [and] learning is a lifelong process (National Level Official).

Capacity building is very important because even those talented leaders need also to learn. So it is good to receive training to improve weak side while maintaining strength (Classroom Teacher).

\section{Barriers affecting leadership roles on ECE in Tanzania}

The implementation of quality Early Childhood Services should ensure that there are no barriers to those taking on leadership and responsibilities. The barriers to all participating groups included, limited knowledge of decision makers on the importance of ECE, lack of budget and resources for ECE, limited training opportunities and over dependence on donor support for ECE programs.

\section{Budget and resource allocations}

The general impression from study participants especially at national level, it that decision makers have limited understanding on the importance of ECE. Although participants acknowledged that ECE was gaining attention at the national level, there was a general view that people who make decisions on resource allocation may lack the necessary knowledge on ECE:

Now when it comes to budget allocation, the people who sit there [in budget meetings], have no idea of what is ECE. So during the budget ceiling, when they look for the things to be omitted, ECE is one of the items to be deleted right away (National Level Official).

The lack of explicit budget allocation affects almost everything including leadership training and the quality of teaching and learning in the Early Childhood Education settings. Tanzania is a good example where the policy is clear 
about the importance of Early Childhood Education but the implementation does not translate the policy into programs and resource allocations.

\section{Gender and leadership}

The issue of gender and leadership was also investigated during the study. At national level out of nine people who were interviewed; only three were women and six were men. At the district level the number was equal, two men and two women. At primary school level there was only one male teacher who was the head teacher and the rest were female teachers. The situation on the ground was not different from the current literature, in that more women work in ECE classes while a few men dominate leadership positions.

\section{Implications and Conclusion}

This paper highlights key findings from the study on the differences between stated policies and implemented policies in Early Childhood Education leadership in Tanzania. Throughout the study as it was the case in the literature reviewed, it is clear that leadership does not explicitly exist in Early Childhood Education in Tanzania.

Therefore in order to improve ECE leadership and the status of ECE the government of Tanzania should increase education funding and clearly allocate budget for ECE activities. The government should provide leadership training and professional support to head teachers and classroom teachers. Efforts should be made to improve communication system in both directions. The role of higher learning institutions cannot be overlooked and therefore the government should involve higher learning institutions in policy development and implementation. The findings suggest that those working in ECE have considerable experience that could inform policy implementation. In the attempt to improve communication bottom up, it is important to acknowledge professional knowledge and experiences of those working in the field. 


\section{References}

Ang, L. (2011). Leading and Managing in the Early Years: A Study of the Impact of a NCSL Programme on Children's Centre Leaders' Perceptions of Leadership and Practice. Educational Management Administration \& Leadership, 40 (3), 289-304

Bogdan, R. C. \& Biklen, S. K. (2007). Qualitative research for education: An introduction to theories and methods. PHI Learning Private Limited New Delhi-110001

Center on the Developing Child at Harvard University. (2007). A Science-Based Framework for Early Childhood Policy: Using Evidence to Improve Outcomes in Learning, Behavior, and Health for Vulnerable Children. Retrieved from: http:// www.developingchild.harvard.edu

Heckman, J.J. (2006). Skill Formation and the Economics of Investing in Disadvantaged Children. Science Vol. 312, 2006, 1900-1902

Ho, D.C.W. (2011). Identifying leadership roles for quality in early childhood education Programmes. International Journal of Leadership in Education: Theory and Practice, 14:1, 2011, 47-59

Merriam, S. B. (2002). Introduction to qualitative research. Qualitative Research in Practice: Examples for discussion and analysis. John Wiley and Sons, Inc.

Mtahabwa, L. (2010). Provision of Pre-primary Education as a Basic Right in Tanzania: reflections from policy documents. Contemporary Issues in Early ChildhoodVol. 11 No 3, 2010, 353-364

Muijs, D., Aubrey, C., Harris, A., \& Briggs, M. (2004). How Do they Manage? A Review of the Research on Leadership in Early Childhood. Journal of Early Childhood Research Volume 2, Number 2, 2004, 157-169.

National Research Council and Institute of Medicine. (2000). From Neurons to Neighborhoods: The Science of Early Childhood Development. Committee on Integrating the Science of Early Childhood Development. Jack P., Shonkoff \& D. A. Philips (Eds.). Board on Children, Youth, and Families, Commission on Behavioral and Social Science and Education. Washington D.C.: National Academy Press.

Ramgopal, P. S, Dieterle K.P, Aviles, J., McCreedy, B. \& Davis, C. F. (2009). Leadership Development in the South: Where Do We Go From Here? Dimensions of early childhood Volume 37, Number 3, 2009, 33-38

Stamopoulos, E. (2012). Reframing early childhood leadership. Australasian Journal of Early Childhood, Volume 37 Number 2, 2012, 42-48. 